Confining the margins, marginalizing the confined: The Distress of Neglected Lockdown Victims in Indian Cities

Rémi de Bercegol, Anthony Goreau-Ponceaud, Shankare Gowda and Antony Raj

(2) OpenEdition

12 Journals

Electronic version

URL: http://journals.openedition.org/echogeo/19357

DOI: 10.4000/echogeo.19357

ISSN: 1963-1197

Publisher

Pôle de recherche pour l'organisation et la diffusion de l'information géographique (CNRS UMR 8586)

Electronic reference

Rémi de Bercegol, Anthony Goreau-Ponceaud, Shankare Gowda and Antony Raj, "Confining the margins, marginalizing the confined: The Distress of Neglected Lockdown Victims in Indian Cities », EchoGéo [Online], Sur le Vif, Online since 14 May 2020, connection on 01 July 2020. URL : http:// journals.openedition.org/echogeo/19357 ; DOI : https://doi.org/10.4000/echogeo.19357

This text was automatically generated on 1 July 2020.

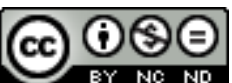

EchoGéo est mis à disposition selon les termes de la licence Creative Commons Attribution - Pas d'Utilisation Commerciale - Pas de Modification 4.0 International 


\title{
Confining the margins, marginalizing the confined: The Distress of Neglected Lockdown Victims in Indian Cities
}

\author{
Rémi de Bercegol, Anthony Goreau-Ponceaud, Shankare Gowda and \\ Antony Raj
}

The survey undertaken on the Delhi slum for this article (Hanuman Mandir Mazdoor Camp) benefited from financial support from the French Agence Nationale de la Recherche (ANR) through Challenging Inequalities: A Indo-European perspective (ANR-18-EQUI-0003).

As a corollary to the diffusion of Covid-19, containment ${ }^{1}$ is now applied in a good number of countries questioning more and more geographers and researchers from other social science disciplines on the characteristics of this arrangement (Arabindo, 2020; Leach, 2020; Poornima Wasdani and Prasad, 2020). Cities have come to a standstill, central districts have been deserted and, wherever it has been possible, the biresidential (or those with families outside the metropolises), those individuals for whom mobility is an element of social distinction as well as emancipation, have left the metropolises for less dense spaces. It seems that "urbanity", a much-vaunted quality sought after by planners, is now being set aside in favour of distance, remoteness and distance. Density, co-presence and saturation are becoming factors of propagation and are said to be at the origin of a high risk of contamination. Whether out of fear or anxiety, going away to live through this isolation "in the green" seems more bearable for those who can afford it than staying in a cramped home in the heart of a Block of highly dense population. This is a matter of square metres, in short, revealing, if we still needed it revealed, the tragedy of ordinary injustices (social of course, but not devoid of a spatial dimension). This is a domestic confinement whose range of situations encountered depends on the material conditions of its occupants. Confinement is a reminder of the extent of inequalities in housing. Proximity or, more precisely, physical contiguity, is now banned in the name of respect for "barrier 
measures" and the famous "social distancing". At the same time, digital connectedness and connectivity are being touted as new paragons of social relations, but they still require equipment (and not living in areas without a signal). Everything seems to be done to maintain social relations despite a brutal spatial rupture that can be summed up in a slogan that is repeated over and over again: "stay home", "stay safe, stay at home". In response to the threat posed by COVID-19, much of what is being asked of people, and for which we are perhaps least prepared, is therefore waiting. This expectation, which is a kind of suspended present that stands in sharp contrast to the speed of the spread of the virus), plunging societies into uncertainty, can be broken down into the now classic triptych of containment, isolation and quarantine, inviting us to rethink our relationship to space and also to time ${ }^{2}$.

2 By imposing a new spatiality, the virus, or its threat, reveals and reinforces deep inequalities. It can be said without shame or digression that social confinement and social distancing are measures that are supported much better by the rich and middle classes than by the poor. Above all, so-called "containment" measures are part of a geographical paradox. In a way, we are witnessing a shift in the centre/periphery relationship, albeit brief and fleeting. In geography, confines are the parts of a territory located at its extreme limit, suggesting distancing from a centrality (Brunet et al., 1993). This distancing can potentially be a source of precariousness (being confined means possibly being relegated ${ }^{3}$ ), but also an opening towards another place (the confines are located at the limit, on the border of another territory), another system and, therefore, potentially a source of innovation. In this respect, the confines can in turn be an interface, a step or a margin. In France, the rural world has become a new centrality for the privileged few whose mobile lives have come to a standstill: within a few hours, the wealthiest sections of the population have massively left the urban centres to return to their second home (or a family home still inhabited by relatives) located in the countryside or in tourist areas marked by strong seasonality, turning a dead time that was supposed to be the "low season", into full time, a periphery into a centrality.

3 This geographical questioning of confines, margins and containment is in India much more delicate and problematic to analyze, because it obliges us, on the one hand, to challenge the very principle of the universality of protective measures taken against the virus. Beyond the case of India alone, the widespread confinement of populations highlights structural inequalities that call into question the uniformity of the response to the health crisis without any distinction. On the other hand, the analysis is problematical in India because the centre/periphery relationships are not so obvious, so clear-cut. In this contribution, through cross situations, we wish to evoke the case of those who have not had the choice to leave. More specifically, we wish to shed light on those who are confined to the margins, and to understand the ways in which they "deal with" their limited space. This means asking ourselves about this spatial distance that has strangely transmuted itself into social distance. The first part will return to the conditions of confinement in India, while the second, through various interviews, will focus on the very harsh conditions faced by the poor populations of Indian cities, relegated to the urban margins. The third and last part will finally address the issue of the impossibility of complying with barrier measures. In the end, our text pleads for a better consideration of these populations confined to the margins, during and after the pandemic crisis. 


\section{Modalities for the implementation of containment in india}

4 Certain that the virus could only be brought in from outside, the Indian Union adopted measures to protect itself from this apparently foreign and imported threat. In this sense, the Indian government first put in place restrictions on the entry of foreigners from China and a handful of other countries (Italy and France in particular), before suspending all visas to enter the country as of March 15. Nevertheless, the Indian Ministry of Health - until March 13, when the total number of officially identified SARCov-2 infections in India was 81 - continued to claim that COVID-19 was "not a health emergency". It is within this specific framework that the brutality of the containment in the country must be analyzed: a lockdown that includes, for the moment, three major temporalities, three acts. The outcome of the play is unknown, as is that of the lives subject to rupture we intend to give voice to.

\section{Act 1: A first run-through, the Janata Curfew}

5 On 19 March, Prime Minister Narendra Modi spoke to the nation in a speech lasting nearly 30 minutes. His speech was covered by the entire media. His mere announcement the day before had raised concerns and even generated a degree of panic among the population. Indians are familiar with periods of "ban" (prohibitions) that usually occur after rapid and violent episodes of social unrest, but there has never been widespread containment in India until now. This is distressing for the population. They all have in mind the imminent announcement of widespread containment. The announcement of a Janata curfew, or people's curfew, for the following Sunday (March 22nd), comforts them while creating a feeling of incomprehension. From 7:00 am to 9:00 pm people are invited to stay in their homes and, at 5:00 pm, to ring bells, blow on conches and applaud those who cannot remain confined and those who are fighting against the virus: one day, one struggle!

\section{Act 2: containment or lockdown}

6 On 24 March, Narendra Modi announced a total lockdown of 21 days from 25 March until 15 April starting at at 09:00, and urged States and Union Territories (UT) to close their borders. In less than four hours, the country is immobilized, frozen, paralyzed, leaving no time for the population to adapt to these strict conditions, however necessary they may be. The effect of COVID-19 on the national economy and the lives of its citizens is becoming increasingly tangible. While all sectors of society are affected by the crisis, it is having a severe impact on the informal ("unorganized") sector where employment is largely contractual. Indeed, if we include agriculture, nearly $92 \%$ of jobs in India belong to the so-called "unorganized" sector, and are thus without social protection. More specifically, one of the largest and most vulnerable labour forces in India is made up of seasonal migrants, who keep the production costs of many labourintensive businesses low. Even agricultural activity depends heavily on landless migrant workers ${ }^{4}$. The flexibility of this labour force has been the main factor of production in agriculture, construction and small-scale industrial activities, to which new sectors, such as home deliveries, taxi rides and the organization of local 
commercial activities in cities (including street vending) have gradually been added, as well as jobs related to domestic services. The effect of the cessation of economic activities and the closure of state borders on these day labourers is catastrophic. The closure of the industry has left workers unemployed throughout the country and deprived them of the opportunity to collect their wages or to make arrangements to leave the cities (Al Dahdah et al, 2020; Samaddar, 2020). Like demonetization ${ }^{5}$, this decision to close the industry completely was taken without any dialogue or consultation with the States and the UTs, and was accompanied by decrees that were implemented after the fact. The lockdown, imposed with great callousness, is accompanied by a cohort of restrictive and prohibitive measures that give rise to intense migration, which is mainly the result of these workers desperately trying to return to their villages. This kind of "urban exodus" is not motivated here by the escape from density, but by the lack of housing and hunger. The national lockdown imposed to combat Covid 19 has left a multitude of these "proletarians" trapped in the in-between roads that separate their workplaces and their villages. This is a humanitarian crisis in the making. As David Picherit (2020) mentions, "the current exodus and the containment measures as applied today reveal, beyond the government's lack of anticipation, expectation of unimaginable/unthinkable class and caste violence".

7 Conversely, little by little, the "middle classes" (in fact the urbanized and cosmopolitan "upper class") have settled into a routine: although they too face challenges, they can work from home and have many leisure options - social media is full of people exchanging recommendations about Netflix and other VOD platforms, as well as home delivery services 6 .

\section{Act 3: the extension of the lockdown, temporary but long lasting}

On 14 April, Narendra Modi announces the extension of the lockdown until $3 \mathrm{May}^{7}$. Even if the modalities of this lockdown vary from one State to another, from one neighborhood to another, depending on the presence or absence of hotspots, for those who are confined to the margins this announcement is a veritable sledgehammer blow. With public transport grinding to a halt, migrants seem to have no other option but to remain trapped on the spot on their way home to their villages and confined to makeshift shelters imposed by the authorities. But this is also the case for other workers leading precarious lives, permanently on the margins, and these men and women cannot suddenly leave everything overnight without a fallback solution. "Staying at home" therefore necessarily happens in the shantytown because it offers a roof over one's head. Having gained relative stability, they could cope with the first three weeks, but the next three weeks seem to them insurmountable. This lasting temporary and exceptional temporality disrupts their daily lives. The unspeakable nature of the crisis is therefore at stake in these "neighbourhoods at the bottom of the hierarchical system of places" (Wacquant, 2006, p.5). Space becomes a matter of struggles. It is an essentially negative place, with the effect of constituting those who occupy it as eternally displaced persons or those excluded from the interior, who are denied, in principle or in practice, the right to rights (the right to possess them, to dispose of them and, above all, to claim them). We thus find the idea of the permanent state of exception proposed by Giorgio Agamben based on his reflection on the liminal situations in which the right is supposed to suspend its own effectiveness (Agamben, 
2003; Grangé, 2018). This state of exception is reinforced because the confinement of the marginalized takes place in a particular political temporality marked by emergency legislation that restricts individual freedoms ${ }^{8}$.

Forwards/backwards/margins/gap/edges, it is indeed with reference to a relational conception of space that the place of margins can be questioned, vis-à-vis both collective categories and social distances. For this precariousness, the structures of daily life often make it impossible to respect the recommended barrier measures. The social promiscuity inside the settlements, the obligation to collect daily income and food, on disused roads or in the few alleys still accessible, and the lack of water and soap makes it very difficult, if not unrealistic, to implement the sanitary measures as applied in Europe and recommended by international bodies.

\section{Confining the margin: diversified situations}

In this section, we wish to compare two situations in which margin containment processes are expressed to varying degrees. First, that of a slum of 372 families packed along a very smelly nala (water evacuation canal) in the middle of the Rama Krishna Puram district, in the centre of South Delhi, and that of a Sri Lankan refugee camp located about twenty kilometers from Pondicherry: two spaces that are distant from each other but whose characteristics and, above all, situations in the face of the pandemic, tend to bring closer together, while extending Michel Agier's questioning: "What about containment as a health protection for populations that are already experiencing a first kind of containment? "(Agier, 2020). Faced with the impossibility of going to the site, the interviews that serve as the empirical basis for our demonstration were conducted by telephone with the inhabitants of Hanuman Mandir Mazdoor Camp (literally, "the Hanuman Temple Workers' Camp", more simply and colloquially called Hanuman Mandir) and the Keezhputhupattu refugee camp9.

11 In both cases, the sites are well known to the authors (Bercegol and Gowda, forthcoming; Bercegol, Davis, Gowda, 2020; Goreau-Ponceaud, 2014, 2015; 2019; Bentz and Goreau-Ponceaud, 2020), who already had the numbers of telephones and relays within these spaces (where ongoing surveys were taking place at the time ${ }^{10}$ ). These interviews, which began as early as the second week of confinement, fall into the crisis period. They are guided by a series of questions organized around five main themes, concerning (1) the virus, (2) access to water and sanitation, (3) housing conditions and neighbourhood, (4) means of subsistence, (5) eligibility for aid. Each phone discussion, conducted in Hindi (for Hanuman Mandir) and Tamil (for Keezhputhupattu), lasts between 20 and 30 minutes. These interviews, which began as early as the second week of the confinement, fall into the crisis period. At the time of writing, there were ten transcribed interviews for Hanuman Mandir, including only one with a woman (Sanjana, cited in the article), and nine for Keezhputhupattu. Given the male gender of the interviewers, it seemed difficult to ask for a wife to be interviewed by telephone, especially in a context of tensions related to confinement. Putting the data collected into perspective reveals strong similarities in terms of the very harsh conditions under which marginal neighbourhoods are confined and how little account is taken of their particularities. At the time of publication of this article, after more than a month of lockdown, these interviews became more complex as the health crisis turned into a 
humanitarian crisis, forcing the authors to activate various relays (friends, civil organizations, political actors) to help the inhabitants as much as they could.

\section{First situation: Hanuman Mandir}

12 According to the latest population census of 2011, there are about 13.7 million households living in slums ${ }^{11}$ in India, 1.8 million of which are in Delhi, or $11 \%$ of the city. The Delhi Urban Shelter Improvement Board counted $757^{12}$ jhuggi-jhopri clusters, i.e. groupings of more or less consolidated huts illegally occupying public land (as is the case of Hanuman Mandir). Living conditions there are very difficult, with an infant mortality rate of 46 per 1,000 (Agarwal et al. 2007) and very limited access to basic services, particularly sanitation and latrines, with $56 \%$ of children forced to defecate in an open area (Delhi Human Development Report, 2013). Urban renewal" policies (a euphemism for the demolition of slums) and the relocation of slum dwellers on the outskirts to lower-value land have often only worsened the living conditions of the inhabitants (Dupont and Vaquier, 2013).

\section{"Stay at home": where is the "home" of the slum dwellers?}

13 The drama of regular policies of demolition, eviction or re-housing (Dupont, 2008; Dupont and Vaquier, 2013; Dupont and Gowda, 2016) reminds us, were it necessary, of the extent to which the "slum" is a category that is above all political (Clerc, 2018) and one that we must know how to question: for those who live there and despite the insalubrity and poverty, the precarious neighbourhood remains above all a home.

"Our life is here, my husband works [as a rickshaw driver] so that our children have a better life than ours; it is for them that we are here. The education system is good in Delhi. We moved to Ravi Das Camp [editor's note: the slum across the street] after I got married and we finally moved here. Back to Assam? But this is our home here, anyway, I am six months pregnant, the question doesn't even arise" (Sanjana, Hanuman Mandir, 17/04/20).

While the vast majority of migrant workers are single men (SWAN, 2020, p. 6) ${ }^{13}$, many families live in these slums. Some even own the walls of their homes ${ }^{14}$, have children in school, and an income, though minimal, that allows them to keep their homes under one roof. Theirs are the small, disregarded jobs of everyday life: informal waste collectors who want to keep privileged access to a particular neighbourhood (Gill, 2009); domestic helpers who cannot bring themselves to lose the few hours they are used to working in this or that house (Neetha and Palriwala, 2011) ${ }^{15}$; guardians of the gated colonies (Carrière 2018), rickshaw drivers who have a loan to repay, or small craftsmen, carpenters, locksmiths; all of them struggling to establish themselves and make a place for themselves in the city.

"We come from Aligarh but there is no work there. Here, my brother and I work in Katwarai Sarai, where we collect materials from the local garbage bins and sell them to the kabari-wala [local scrap dealer]. Between the two of us, we manage to earn about 15,000 rupees a month. It's better than nothing even if it's barely enough to support the family: he has five children and I have three. We have to be able to work, it's vital" (Mahender Singh, Hanuman Mandir, 05/04/20).

For these poor mazdoor [manual workers], the preservation of their work, however insignificant it may seem to some, is of crucial importance, which explains their urban roots. The initially announced 21-day period suggested to these workers that their 
economic gains could be preserved until they returned to "normal" life. Reaching their village, sometimes on foot and under police bullying, as is happening to construction workers (Nath Roy et al., 2017), is not an option for those who have settled permanently in the city with the hope of a social ascent, an ascent that is in fact very constrained (Mitra, 2010).

"No, we do not own land in the village in Uttar Pradesh, neither my father nor my grandfather [...]. In the village, I didn't even have enough money to dress the children properly. We try to go back every year, which is important, but it is expensive, and we have to make sure that we are replaced at work here in Delhi while we are away. There's no point in leaving in a hurry. I called my parents and they told me it's better to stay in Delhi. The government should have given 2 days of preparation for those who can afford to leave" (Om Prakash, Hanuman Mandir, 14/04/20).

The hope of a hypothetical village retreat remains a powerful motivation to endure the daily grind but in the meantime it is indeed the city that has concrete opportunities that rural areas cannot offer. Returning to the village, even temporarily, cannot be spontaneous but must be prepared months in advance. Without any prospect of improvement in the short term any hasty move is unthinkable because it is devoid of result.

\section{"No work, no money, no food."}

17 With the sudden economic downturn ${ }^{16}$, slum dwellers saw their livelihoods disappear overnight. The inhabitants certainly fear the virus, but without work and income it is the fear of not being able to feed themselves that dominates (Parulkar, Naik, 2020).

"I don't dare to go out and collect waste because no one will buy the materials from me anymore, Papu [the kabariwala] has no place to store because he can't sell it either, and I'm afraid that the police will attack me and take away my cart. I have seen that the waste is now being collected by garbage trucks, it's over for us, what can I do? Nobody helps us, neither the government, nor politicians, nor associations. I have no job, I have no money, I have no food, I have no gas, I have nothing. The labour chowk [labour market] is closed, I know the virus is dangerous, but if I don't find money soon, my family will go hungry" (Surender Kumar, $30 / 03 / 20$ ).

Without a source of income, the poor inhabitants are heavily dependent on the aid put in place by the government to compensate for the lack of income of the working poor. To this end, the Minister of Finance has announced that the Gareeb Kalyan Yojana (Social Protection Scheme for the Poor mainly intended to facilitate access to food through the Public Distribution System (PDS ${ }^{17}$ ) as well as to provide direct financial support to beneficiaries) would cover these needs under the National Food Security Act of 2013. However, the overall amount of aid has been denounced as "embarrassing" (Gosh, 2020) given the low level of resources allocated (0.5\% of GDP) in view of the socio-economic damage of the lockdown among the poor. In fact, those (but not all) who have a Jan Dhan ${ }^{18}$ bank account received only 500 rupees of aid, barely equivalent to what they had previously earned over one or two days, a sum very insufficient to survive the time of the lockdown. In addition, many workers do not have the necessary administrative documents to enable them to benefit from this aid, nor do they know how to use a bank account and may not have one, as their daily income, limited to a few hundred rupees, does not justify the interest. It is worth noting here the responsiveness of Safai Sena, a non-governmental organisation which aims to defend the rights of workers in the 
waste sector, and which was very quickly able to distribute 1500 rupees to Hanuman Mandir's unionised waste pickers. This is not enough, but it is more than the amount the government paid into the Jan Dhan accounts.

Most families do not have the capacity to store food reserves for more than a week, and small quantities are usually purchased on a day-to-day basis. Without work or money, caloric intake is therefore greatly reduced during confinement. Both parents and children eat little and less and less as the days go by. However, India benefits from an extensive Public Distribution System (PDS) with an impressive network of 500,000 shops theoretically allowed to support eligible people, i.e. $67 \%$ of the Indian population (the households categorized Antyodaya Anna Yojana - AAY- and Priority Households - PHH). Beneficiaries can receive $5 \mathrm{~kg}$ of rice per person, up to $35 \mathrm{~kg}$ per grain family, at subsidized prices of 3 rupees $/ \mathrm{kg}$ for rice, 2 rupees for wheat and 1 rupee for other cereals (millet and millets) and pulses (against 40 rupees $/ \mathrm{kg}$ for rice and 25 rupees $/ \mathrm{kg}$ for wheat at commercial market prices in 2020). Under the Delhi confinement, eligible families will receive an additional ration free of charge for 3 months ${ }^{19}$. But in a country of 1.4 billion inhabitants, getting aid to the people is a major challenge, all the more difficult to put into operation because the many malfunctions slowing down the logistics chain are reinforced during the lockdown period ${ }^{20}$. In addition to the problems of diversion that existed prior to the crisis (Landy 2014), and the lack of manpower due to containment, it is above all the problems of identifying beneficiaries that burden the system. As is the case with many migrants (Mukhopadhyay and Naik, 2020) many eligible families cannot benefit from food distributions because their ration cards are not up to date in the Aadhar digital system (biometric identity cards), either because they are still registered in their village of origin or because of a registration problem in Delhi itself.

"I used to have a ration card, but it doesn't work anymore. My jhuggi is at $\mathrm{n}^{\circ} 170$ but on the new card, they marked n ${ }^{\circ} 171$, I didn't notice at the time, and I was able to continue to get the food rations for 3-4 months before I was forbidden. I tried to get it rectified but it was a waste of time, so I gave up. I do have a Jhan Dan account, but nothing was paid into it. I don't know the official programs, everything is provided for those who can read, but not for others" (Mahender Singh, Hanuman Mandir, 05/04/2020).

In this context of humanitarian emergency, the implementation of an online system of "temporary ration e-cards ${ }^{21 "}$ by the government of Delhi is welcome, but the registration process remains difficult for families who are not always aware of this type of initiative and/or do not have internet connection and who regret the small quantities distributed (4 $\mathrm{kg}$ of wheat and $1 \mathrm{~kg}$ of rice per member).

21 To address these shortcomings, the Delhi government has urgently set up hot meal distributions twice a day in more than 600 "relief centres" throughout the city. In Hanuman Mandir, the neighbouring school was requisitioned to provide these meals composed of rice, dal (lentils) and sometimes khichidi (a dish composed of rice and lentils).

"I don't go there, there are too many people and not all are served, it is dangerous for the virus, and then I am afraid of being hurt by the crowd, to save 10 rupees of food I would have to risk spending 1000 rupees in the hospital. We do have Aadhar card, voter's card, ...but no ration card! My aunt at Ravis Das Camp [opposite Hanuman] has one and she shares her ration with us. She gave us $5 \mathrm{~kg}$ of rice, how long are we going to last? We don't even have any gas left, we cook with wood and there's hardly any gas left already. My husband borrowed 50 rupees to buy milk for 
my two children [one and three years old], but who will be able to lend him every day? .... We eat less and less, first the children and then us. Before, when my husband was working [as a Tempo driver], he used to earn sometimes 800 rupees a day and he would bring me mango juice, fruits, vegetables, we even used to go to restaurants sometimes, but that's all over now. We just sold one of our phones for 550 rupees to a neighbour because the most important thing in life is to feed the children, but we have nothing else to sell now, I don't know what will happen next" (Sanjana, Hanuman Mandir 17/04/20). organizations is essential to the delivery of hot meals and, above all, food rations ${ }^{23}$. Thanks to good local relays, their capacity of identification is facilitated, but their means of action remain limited by the constraints on human and financial resources in the face of the increasing number of needy families, with the risk of riots during food distributions, the restrictions of mobility due to police control and of course the danger of the virus.

\section{Second situation: Keezhputhupattu refugee camp}

Located about 20 kilometres north of Pondicherry along the East Coast Road, Keezhputhupattu camp is home to nearly 450 families, representing a total of 1,726 Sri Lankans, the vast majority of whom arrived in the 1980s and 1990s. The situation there is much less catastrophic than in Hanuman Mandir even though the residents are not Indian citizens. Within the camp, individual housing is organized according to an orthonormal plan. The alleys are narrow, made of unpaved earth. Electricity and water are provided free of charge by the government. The shelters are simple, built of concrete, including the floor, and with a tin roof. Their size is standardized: a square of 10 feet on each side (a little more than 3 metres). But as a refugee already stated in 2014, "generally speaking, in the camp it is $40 \%$ government aid and constraint, and $60 \%$ private initiatives" (Thiraviyam, Keezhputhupattu camp, July 18, 2014). Refugees are so used to the rules and to tinkering day by day with solutions to deal with the constraints that weigh on them. Their housing made of concrete bears witness to this particular temporality between the permanence of the buildings and the transitory nature of refugee status (Abourahme, 2015, p. 210 and 214). Many Sri Lankans believed that the displacement would be only temporary and would end when the violence and conflict did (officially ended in May 2009). Over time, however, this hope gave way to a sense of prolonged time, characterized by a long wait. In the end, many refugees 
resigned themselves to accepting a "normalization of the temporary", which proved to be a strength in coping with the pandemic. In addition, the "encamping" conditions (Agier, 2011) of Sri Lankans have evolved in response to the security situation. While initially the attitude towards them of the governments of New Delhi and Tamil Nadu was benevolent, the situation changed after the assassination of Rajiv Gandhi on 21 May 1991. The fear of importing Tamil separatism into India immediately led to an intensification of the encamping policy and the setting up of repatriation operations, not always on a voluntary basis.

The vast majority of families residing in Keezhputhupattu camp are from the island of Mannar. Together with Tibetans, Sri Lankans are considered to be the group of refugees most favourably treated by the Indian authorities. They have been widely accepted by India and, once registered with the authorities, they receive financial assistance and food at subsidized prices. All the refugees living in Keezhputhupattu camp have an Adhaar card and a ration card. This gives them access to the PDS. The central government of New Delhi and especially the government of Tamil Nadu grants them monthly financial aid: 1,000 rupees for the "head of the family", which is not much and represents the amount usually earned in two days of work: 750 for his wife and 400 for other family members, and 1,000 rupees per month for people over 65 years old, widows and the destitute.

While movement outside the camp is officially all under control and requires multiple permits, in " normal times ", refugees find employment outside the camp, mainly in physical and low-skilled jobs (construction and building, and fishing in particular) that are sometimes very remunerative. Nevertheless, lockdown undermines these ordinary acts of resistance and tests the networks of sociability, without, however, undermining them too drastically. It has also resulted in the strengthening of police presence around and in the camp. Staying at home is difficult for the refugees; it condemns them to dipping into their savings.

"The first week after the lockdown was announced, we all followed the rules very closely. I stayed at home, in the camp. We had a few supplies and it was pretty easy to count on it for food. But after a week it became very difficult. It was not possible for me, when I looked at my children, to see the hunger in their eyes ${ }^{24}$. So I made the decision to leave the camp during the day to find a job. But since the lockdown, it is impossible to find a job and therefore to earn money. Anyway it is impossible to leave the camp. It is stricter than normal. The police are always present. Sometimes they even enter the camp to check that people are at home. So I borrow money from different people: Raman from whom I borrowed 1,000 rupees, Karthick (500 rupees) and my Mestry [recruiter] gave me an advance of 1,000 rupees. So I did what I could with the money until today (09/04/2020). But I already have nothing left. I have to find another way to survive. I'm a carpenter, and for the last three days I've been working again on a building site in Pondicherry [...] I've been able to keep this job thanks to my links with the camp manager who covers my absences. He covers my absences because I have redone everything in his house without ever being paid. He had a kind of debt, he's paying it off now. Besides, the building site I am working on at the moment is the house of the mother of an important MLA (Member of Parliament) from Pondicherry. So I was able to get a pass which allows me to easily cross all the check post between the camp which is in Tamil Nadu and the house which is located in Pondicherry. I don't even know what it says on it, it's in English, but I think it's something like 'Covid 19 E-pass'" (Mugandan, 11/04/20. Mugandan lives in Keezhputhupattu camp with his wife, mother and three children). 
Mobility control is sometimes stricter in other camps.

"We're only allowed to be away from camp for two hours a day. We have to sign the register. Camp Surpervisor is very strict on this point. All our movements are scrupulously noted and recorded on this register. At the beginning of the lockdown, one person of the camp did not respect this new rule and only came back in the evening. The camp supervisor made a report asking for the cancellation of the financial aid from the government for one month as well as their ration of rice and other provisions to which they are entitled at the ration shop. He also locked the door of his house with a lock with all the occupants inside and asked all the camp residents not to speak to them for three days or face similar punishment" (Sunam, 20/04/20, Kattumanarkoil camp).

Mugandan, thanks to the networks he has gradually built up, is the only one to enjoy this total freedom of movement and one of the few to have been able to keep his job. Anthony, another refugee who with his wife Vetha owns one of the few shops in the camp, has not been so lucky. He nevertheless won (under cover of a regular fruit and vegetable contribution to the police) permission to go to the market in Pondicherry to restock his supplies. But sales in his stall are on credit, and the purchase of food is a drain on his savings, which are shrinking fast and aching like a sore thumb. Like the other refugees, he is worried about the coming weeks.

"It's very difficult for everyone at the moment. There is no more work. But it's true that we are receiving help from the government, and recently there is even a school in the Immaculate Conception in Pondicherry that provides us with food. There are also other NGOs that help us" (Anthony, Keezhputhupattu, 14/04/2020).

What our interviews reveal is also a peculiarity of this segment of the population that has substantial savings. The situations encountered in the camps are certainly less difficult, but still precarious, unstable and uncertain.

"Because we are Sri Lankan refugees, we are not Indian citizens and we don't have voting cards, people involved in politics are not worried about us. In the neighbourhoods next to our camp, the MLA [Member of Parliament] came to give rice, sugar, oil. No one comes here. But what saves us are our savings" (Sunam, 20/04/20, Kattumanarkoil camp).

\section{Respecting barrier measures: geographical detours concerning social distance}

Thanks to public announcements, television, radio and mobile phones, people have all become well aware of the danger of the virus, contrary to what a certain part of the press pointed out at the beginning of the epidemic. Nevertheless, the containment is taking place in conditions that reflect a problem of insalubrity and poverty that the current period of the pandemic is only revealing; the health conditions as well as the social effects are likely to worsen the living conditions of the populations.

\section{Respecting sanitary measures}

Given the promiscuity and reduced access to water supply services, the "barrier gestures" promulgated by the health authorities, which must be applied without distinction according to countries and regions, are very difficult to translate into action. In 2011, 35\% of urban households in India live in only one room (Census 2011), and all slum households are overcrowded: with an average of 4 to 5 members, the 
whole family sleeps in a single small shack of barely a few square metres ${ }^{25}$, where they cook, work, play and live out in front of the rest of the day. In Hanuman Mandir, which covers an area of 2.2 hectares and is home to over 1,500 people, the density is so high ${ }^{26}$ that "spatial distance" between the inhabitants is obviously impossible to achieve. This density is lower in the Keezhputhupattu camp, which has around 1,726 inhabitants on a surface area of 3.5 hectares. We will see that the contrasts between these two margins are colossal.

"What to do? We can't stay locked up, so people are roaming within the camp, and hide when the police arrive. We are all afraid, but for the moment there is no contamination in our slum. The Pradhans have banned outsiders from entering after a vegetable seller tried to enter last week. And now it is almost impossible to go outside, except for getting food" (Mr. Ishwar, Hanuman Mandir, 30/03/20).

This constrained and prolonged proximity in a crisis context fosters tensions, both between neighbours and within the household, especially around the issue of food. Tensions are particularly high during food aid distributions. Within the households themselves, the testimonies tend to reflect relative goodwill between the spouses (which can be explained by the temporary absence of alcohol, the sale of which is prohibited during the lockdown), but which unfortunately needs to be put into perspective given the general increase in domestic violence reported by the media ${ }^{27}$. In the Keezhputhupattu camp, conflicts with neighbours regularly lead to physical clashes, but the lack of alcohol is generally peaceful in its effects here too.

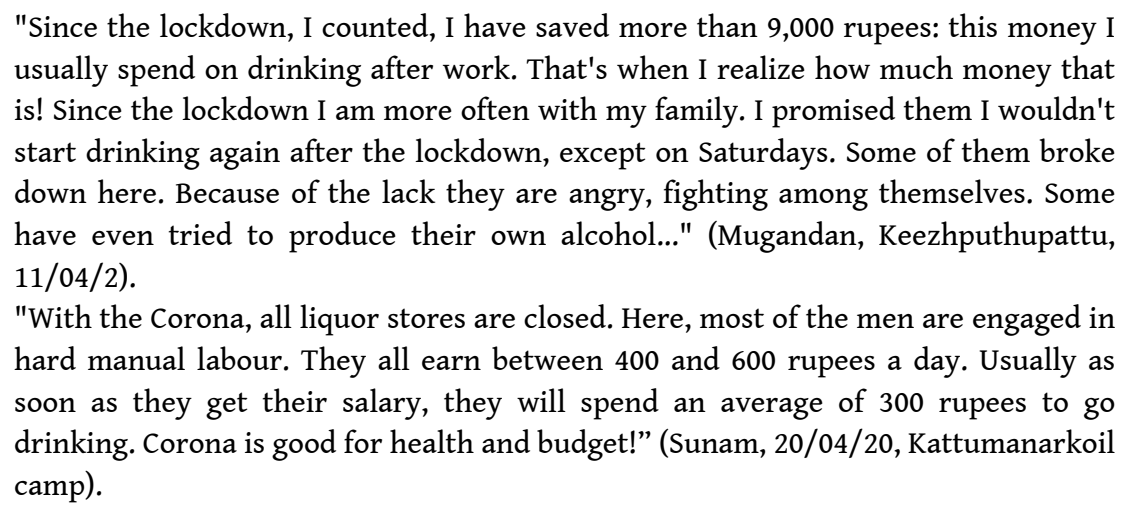

"With the Corona, all liquor stores are closed. Here, most of the men are engaged in hard manual labour. They all earn between 400 and 600 rupees a day. Usually as soon as they get their salary, they will spend an average of 300 rupees to go drinking. Corona is good for health and budget!" (Sunam, 20/04/20, Kattumanarkoil camp).

On the other hand, the "social distancing" of the slum dwellers from the nearby middle class neighbourhoods, which existed before the crisis, is being reinforced. The physical violence used by police with truncheons to harshly repress those who dare to venture outside (only quick runs in the immediate vicinity are allowed) is the main reason for the respect of the confinement: the fear of the lathi even more than that of the virus.

\section{A highly constrained hygiene}

Regular hand washing is not an easy undertaking for everyone in India, where $20 \%$ of urban households do not have sufficient access to water (Guilmoto and Licart, 2020). With $90 \%$ access to safe drinking water, Delhi is better off than most other states. However, this reality conceals significant geographical disparities depending on the districts where the Delhi Jal Board's municipal network is struggling to serve all the inhabitants (Kacker and Joshi, 2012). In Hanuman Mandir, there are no individual connections, and families have to share the approximately 20 public taps available, i.e. about 10 to 20 families per water point. There are two blocks of public toilets, which are 
now free of charge (previously 2 rupees) but remain poorly maintained, and which children avoid using (defecating in the open nala). In Keezhputhupattu camp, there is on average one public tap every 20 metres. The camp is also equipped with two blocks of public toilets. But the vast majority of the refugees have taken the lead in the face of this ongoing temporary situation. The situation is similar in the other camps.

"All the houses have access to water, there is a tap every 20 metres, but over time some of the refugees have been able to equip themselves. For example, I have my own water tap inside and I have another one outside. We let our neighbours use it. The water supply is really not a problem within the camp. The water is free and there is plenty of it. That's good because the number of showers since the beginning of this pandemic has exploded as well as the number of hand washing. We use 3 to 4 times more water than usual. We don't even know where to put our soap anymore. Everyone uses their own soap. We all do this in the camp. Fortunately, for the moment no one has been contaminated. Only one person has gone into quarantine and since his return, while he is negative to the test, he is treated as an untouchable" (Anthony, Keezhputhupattu camp, 16/04/2020).

"We are 82 families living in this camp. 70\% of the people have their own taps inside their homes and are connected to the grid. For the others, there are public taps. There are 10 of them in the camp. For drinking water, as in the other camps, we buy 20-litre bottles. It's 7 rupees a per watercan" (Kandasamy, 20/04/20, Virudhachalam camp).

It is clear that the cost of N95 masks (or the purchase of hydro-alcoholic gel) is unaffordable for the inhabitants, who are forced to implement low-cost compensatory strategies, such as covering their faces with a simple scarf, which must then be washed with water. In some camps, women have been trained in sewing, and make masks for the whole community.

"How could we buy masks without money? My wife just puts her duppata [light scarf] in front of her face to protect herself when she goes to fill the water early in the morning before it gets too crowded. There are about a dozen families on the same water point, so we make sure we don't all go at the same time. She doesn't wash her [scarf] every day, and I don't wash my handkerchief either, but we are careful to wash well our hands before eating, at first even with 'Dettol' in hot water, but we are saving LPG (gas) now" (Surender Kumar, Hanuman Mandir, 15/04/20).

"We can't afford to buy disposable masks. It's way too expensive. To do it right, we would have to spend more than 400 rupees a day for the whole family. So we use scarves and cloth masks. We both have each other. This allows us to rotate. We wash them by boiling water to which we add Dettol" (Vetha, Keezhputhupattu, $12 / 04 / 20)$.

"There are 20 seamstresses in the camp. From the beginning of the lockdown, they made masks to give them for free to the people living in the camp" (Sunam, 20/04/20, Kattumanarkoil camp).

While access to water infrastructure is insufficient in Hanuman Mandir, it is still relatively better than in many other slums not connected to the network because they are newer and more peripheral. The inhabitants of Madampur Kadar (one of the many other more recent slums in South Delhi) have to buy water jerrycans (10 rupees per 20 litres). The government of the Delhi Territory tries as much as possible to organize deliveries of drinking water by tanker truck in the areas it manages to identify (and it is important to underline here its reactivity ${ }^{28}$ ) but this is struggling to compensate for a lack of infrastructure. However, major urban renewal programs have multiplied in recent years, from the emblematic Smart City Mission, which succeeded the Jawaharlal Nehru Urban Renewal Mission, or like the Pradhan Mantri Awas Yojana, a program for access to housing, or Swach Bharat Abhiyan, which promotes access to sanitation. But 
despite their scale and priority needs, particularly in terms of the health of the inhabitants, none of them has been implemented with the same intensity as the national lockdown, whose socio-economic cost will be infinitely higher (estimated by Barclays at $\$ 234.4$ billion, or $8.1 \%$ of $\mathrm{GDP}^{29}$ ).

\section{Conclusion}

The generalized lockdown of populations highlights structural inequalities that call into question the uniformity of the response to the health crisis. The various testimonies collected in Hanuman Mandir and Keezhputhupattu show that in spaces relegated to the margins, the impact of the lockdown is extremely violent for the inhabitants. In slums in particular, pre-existing inequalities are reinforced at their peak: insufficient access to water and sanitation can increase the effects of the health crisis tenfold; overcrowding in slums makes it impossible to physically distance oneself from them; and of course, the lack of social protection directly endangers the lives of families who have no means of subsistence.

Between the time this article was written and its publication, the media in India reported several deaths indirectly related to confinement, with people and children dying of starvation and suicides of fathers of indebted families ${ }^{30}$. The suffering of these precarious populations has become even more acute with the successive extensions of a confinement that tends to become established over time. Interviews with the inhabitants now show a greater mistrust of this lockdown, which could end up killing them before the virus takes over: "If this lockdown lasts another month, we will die of hunger" (said Radha on 5 May, a resident of Hanuman Mandir, worried about the new extension of the lockdown until 18 May). After a month and a half of confinement, for most of the inhabitants, the uncertainty about being able to support their families on a day-to-day basis now exceeds the fear of the virus.

In these marginalized areas, the lack of access to essential services and food security are evidence of long-identified structural failures that the confinement dramatically exacerbates with unprecedented violence. It is therefore more necessary than ever to take better account of these populations on the margins, during and after the pandemic, so as not to add the humanitarian crisis to the health emergency. The comparison between Hanuman Mandir and Keezhputhupattu reminds us that India has the effective tools and means necessary to meet the basic needs of precarious populations. In the Keezhputhupattu camp, government aid works despite the crisis thanks to a better institutional recognition of the (de facto and not de jure) status of refugees, which has long allowed them to benefit from monthly food distributions and modest financial support, which somewhat alleviates the difficulties linked to confinement. In Hanuman Mandir, on the other hand, the suffering of the inhabitants is accentuated by administrative problems which make them ineligible for access to aid. The lack of infrastructure due to the illegal status of the neighbourhood makes their presence illegitimate.

40 The standard application of the lockdown, by denying inequalities between citizens, has quickly become unsustainable for those living on the margins. Without effective consideration of the social aspect, this unilateral and indiscriminate application of lockdown condemned part of the population to avoidable torments. The camp and the slum constitute the real space where citizenship (and the acts of citizenship) can be 
arbitrarily questioned, where individuals are translated into simple biopolitical bodies (that can be beaten with lathis), an adjustment variable allowing the economy to be competitive. In these times of pandemic, more than the camp, slums as a political technology is precisely the way in which de-subjectivation is made operational and can be carried to extreme manifestations. This is what the Indian government lacks, and to which it is applying a copy of solutions to the pandemic designed elsewhere,

"[...] is perhaps to recognize beyond life as sacred and suffering as value, the other as a face..., that face present in its refusal to be contained, that face which resists all attempts to possess it, including in the name of good. From this perspective, to recognize a face is also to recognize a right, beyond any obligation, and therefore a subject, beyond any subjection, even to humanitarian reason" (Fassin, 2010, p. 329). call for justice. They also denounce solutions coming from elsewhere, imposed without discernment and anticipation, and chosen according to multiple interests that make these populations governed targets. The fact remains that all these marginalized people demand the right to have their essential rights respected and applied.

\section{BIBLIOGRAPHY}

Abourahme N., 2015. Assembling and Spilling-Over: Towards an 'Ethnography of Cement' in a Palestinian Refugee Camp. International Journal of Urban and Regional Research, vol. 39, $\mathrm{n}^{\circ} 2$, p. 200-217.

Al Dahdah M., Ferry M; Guérin I., Venkatasubramanian G., 2020. The Covid-19 Crisis in India. A Nascent Humanitarian Tragedy. Books and Ideas, [En ligne], URL: http://www.booksandideas.net/ The-Covid-19-Crisis-in-India.html

Agamben G., 2003. État d'exception. Homo Sacer, II, 1. Paris, Le Seuil, 160 p.

Agarwal S., Srivastava A., Choudhary B., Kaushik S., 2007. State of urban health in Delhi. New Delhi, Urban Health Resource Centre, 98 p.

Agier M., 2020. Personnes migrantes en centres de rétention et campements. Désencamper pour protéger. De Facto [En ligne], nº 18.URL: http://icmigrations.fr/2020/04/07/defacto-018-01/

Agier M., 2011, Le couloir des exilés. Être étranger dans un monde commun. Paris, Éditions du croquant.

Arabindoo P., 2020. Pandemic cities: Between mimicry and trickery. City \& Society, [En ligne]. URL: https://doi.org/10.1111/ciso.12263

Auyero J., 2019. Faire patienter, c'est dominer : le pouvoir, l'État et l'attente. Entretien réalisé et traduit par Étienne Ollion. Actes de la recherche en sciences sociales, n²26-227, p. 120-125.

Bentz A.-S., Goreau-Ponceaud A., 2020. To be or not to be a refugee? Reflections on refugeehood and citizenship among Sri Lankan Tamils in India. Citizenship Studies [En ligne], vol. 24, $\mathrm{n}^{\circ} 2$, p. 176-192. DOI: https://doi.org/10.1080/13621025.2019.1706446 
De Bercegol R., Davis G., Gowda S., 2020. The People of Waste. Living Plastic. Documentaire $18 \mathrm{~min}$ 35 s, IRD-CNRS. URL: https://www.youtube.com/watch?v=ZROTSb2TRsk

De Bercegol R., Gowda S., (à paraître), Nettoyer l'Inde : la marginalisation des récupérateurs de déchets à Delhi. Dynamiques environnementales [En ligne] (accepté pour publication).

Brunet R., Ferras R., Théry A., 1993. Les mots de la géographie, dictionnaire critique. Paris Montpellier, La Documentation française - RECLUS, 518 p.

Carrière D., 2018. Filtering Class through Space, Security guards and Urban Territories in Delhi, India. $\mathrm{PhD}$ dissertation, Geography, Université Paris VII Diderot, France, 2015-2018 and University of Minnesota, USA, 2012-2018.

Clerc V., 2018. Rethinking the category of "slum". From Damascus to Yangon, precarious settlements through the prism of urban policies. Revue internationale et stratégique, $\mathrm{n}^{\circ} 112$, p. 139-148.

Dupont V., 2008. Slum demolitions in Delhi since the 1990s: An appraisal. Economic and Political Weekly, n 43 , p. 79-87.

Dupont V., Vaquier D., 2013. Slum demolition: Impact on the affected families, and coping strategies. In Saglio-Yatzimirsky M.-C., Landy F., Megacity Slums. Social Exclusion, Urban Space and Policies in Brazil and India. London, Imperial College Press, p. 307-361.

Dupont V., Gowda S., 2016, Settlement story 4.1. The challenges of communication and participation in slum rehabilitation projects - the Tehkhand and Kathputli Colony projects in Delhi. In Dupont V., Jordhus-Lier D., Sutherland C., Braathen E. (eds), The Politics of Slums in the Global South. Urban informality in Brazil, India, South Africa and Peru. Routledge, Abingdon, p. 79-85.

Fassin E., 2010. La raison humanitaire. Une histoire morale du temps présent. Paris, Le Seuil, 358 p.

Gilbert P., 2020. Le covid-19, la guerre et les quartiers populaires. Métropolitiques [En ligne], URL: https://www.metropolitiques.eu/Le-covid-19-la-guerre-et-les-quartiers-populaires.html

Gill K., 2009. Of poverty and plastic: scavenging and scrap trading entrepreneurs in India's urban informal economy. Oxford, Oxford University Press, $304 \mathrm{p}$.

GNCTD - Government of National Capital Territory of Delhi, 2013. Delhi Human Development Report, 2013. Institute for Human Development et Academic Foundation, New Delhi.

Goreau-Ponceaud A., 2020. Un confiné parmi d'autres à Pondichéry. LAM en parle [En ligne]. URL: https://lamenparle.hypotheses.org/2199

Goreau-Ponceaud A., 2019. Pratiques et vécus des situations de marges : le cas des réfugiés srilankais en Inde. In Bernier X. (dir.), Mobilités et marginalités. Rennes, Presses universitaires de Rennes, p. 59-79.

Goreau-Ponceaud A., 2015. De Ceylan Quarter à Keezhputhupattu : lieux de l'exil sri-lankais en Inde. Les Cahiers d'Outre-mer [En ligne], n 267, p. 261-284. DOI: https://doi.org/10.4000/com.7218 Goreau-Ponceaud A., 2014. À demeure en exil. Être réfugié tamoul sri-lankais au Tamil Nadu. Carnets de géographes [En ligne], $\mathrm{n}^{\circ}$ 7. DOI: https://doi.org/10.4000/cdg.418

Gosh J., 2020. Indian economy was rolling down a hill. With Covid-19, it's falling off a cliff. Quartz India, [En ligne]. URL: https://qz.com/india/1830822/coronavirus-may-push-indias-strugglingeconomy-off-the-cliff/

Grangé N., 2018. L'urgence et l'effroi. L'état d'exception, la guerre et les temps politiques. Lyon, ENS Éditions [En ligne]. URL: http://www.openedition.org/6540 
Guilomoto C.-Z., Licart T., 2020. India and coronavirus: lack of access to handwashing facilities among poor makes fight even harder, The Conversation [En ligne], URL: https://

theconversation.com/india-and-coronavirus-lack-of-access-to-handwashing-facilities-amongpoor-makes-fight-even-harder-135087

Kacker S.D., Joshi A., 2012. Pipe Dreams? The Governance of Urban Water Supply in Informal Settlements. IDS Bulletin, vol. 43, $\mathrm{n}^{\circ}$ 2, p. 27-36.

Landy F., 2014. Gouvernance verticale, corruption et clientélisme. Revue européenne des sciences sociales [En ligne], vol. 52, $\mathrm{n}^{\circ}$ 2, p. 105-131, URL: http://journals.openedition.org/ress/2811 - DOI: https://doi.org/10.4000/ress.2811

Leach M., 2020. Echoes of Ebola: social and political warnings for the COVID-19 response in African settings [En ligne]. URL: http://somatosphere.net/forumpost/echoes-of-ebola/

Mitra A. 2010. Migration, livelihood and well-being: Evidence from Indian city slums. Urban Studies, vol. 47, $\mathrm{n}^{\circ}$ 7, p. 1371-1390.

Mukhopadhyay P., Naik M., 2020. Migrant workers distrust a state that does not take them into account, Indian Express, [En Ligne], URL: https://indianexpress.com/article/opinion/columns/ coronavirus-lockdown-covid-19-deaths-cases-mass-exodus-migrant-workers-6339152/

Nath Roy S., Manish Naik. M, 2017. Migrants in Construction Work: Evaluating their Welfare Framework. Policy Brief, Centre for Policy Research [En ligne], URL: https://www.cprindia.org/ research/reports/migrants-construction-work-evaluating-their-welfare-framework

Neetha N., Palriwala R., 2011. The absence of state law: Domestic workers in India. Canadian Journal of Women and the Law, vol. 23, $\mathrm{n}^{\circ} 1, \mathrm{p}$. 97-120.

Nordman C.-J., Guerin I., 2018. The shock of Indian demonetisation: a failed attempt to formalize the economy. The Conversati [En ligne]. URL: https://theconversation.com/the-shock-of-indiandemonetisation-a-failed-attempt-to-formalise-the-economy-93328

Parulkar A., Naik M., 2020. A Crisis of Hunger: a ground report on the repercussions of COVID-19 related lockdown on Delhi's vulnerable populations [En ligne]. Centre for Policy Research. URL: https:// cprindia.org/research/reports/crisis-hunger-ground-report-repercussions-covid-19-relatedlockdown-delhi\%E2\%80\%99s

Picherit D., 2020. En Inde les travailleurs migrants abandonnés à leur sort. The Conversation [En ligne]. URL: https://theconversation.com/en-inde-les-travailleurs-migrants-abandonnes-a-leursort-135851

Poornima Wasdani K., Prasad A., 2020. The impossibility of social distancing among the urban poor: the case of an Indian slum in the time of COVID-19. Local Environment. The International Journal of Justice and Sustainibility, vol. 25, n 5, p. 414-418. DOI: https://doi.org/ $10.1080 / 13549839.2020 .1754375$

Samaddar R., 2020. Borders of an epidemic. COVID-19 and migrant workers. Kolkata, Mahanirban Calcutta Research Group, 139 p.

SWAN (Stranded Workers Action Networ), 2020. 21 Days and Counting: COVID-19 Lockdown, Migrant Workers, and the Inadequacy of Welfare Measures in India [En ligne]. URL: https://im.rediff.com/ news/2020/apr/16swanreport_final.pdf

Wacquant L., 2006. Parias urbains. Ghetto, banlieues, État. Paris, La Découverte, 332 p. 


\section{NOTES}

1. In spite of the very great heterogeneity of the measures and situations brought together under this term, the media like to point out that more than half of humanity is now "contained".

2. As Javier Auyero notes, waiting "shapes behaviours and confines claims, first and foremost among the poor, who face this asymmetrical situation more than others" (2019, p. 120).

3. It can even be said that for those who live in so-called working-class neighbourhoods in France, it is a double punishment (Gilbert, 2020).

4. This vulnerability of seasonal migrants is exacerbated by their caste identity. Recall that caste determines the ability to accumulate wealth, income and thus the ability to send money to those who stay or migrate. The majority of these migrants belong to lower castes.

5. On 8 November 2016, Narendra Modi declared the demonetization of the Rs 500 and Rs 1,000 banknotes, which accounted for $86 \%$ of the country's cash available, to combat counterfeiting, tax evasion and the informal economy. New Rs 500 and Rs 2,000 notes are being issued to replace the demonetized notes. This demonetization policy has had dramatic effects on the economy, causing a drop in GDP. It is estimated that about 1.5 million jobs were lost in the 6 months following the demonetization (Nordman and Guerin, 2018).

6. Many of these families continued to use the services of their domestic workers, violating the government's call for containment (https://scroll.in/article/958761/middle-class-entitlement-isweakening-indias-battle-against-the-coronavirus).

7. The order issued by the Ministry of Home Affairs has extended the lockdown period by two more weeks, from May 4 onwards, and has provided for different levels of precautions to be undertaken in Red (hotspots), Green and Orange zones - depending on the risk profile of the area. Under the order, some activities will remain prohibited across the country in all the zones, irrespective of their category.

8. Giorgio Agamben published a column in the newspaper Il Manifesto ("Coronavirus and the state of exception", 26 February) which provoked criticism because, based on the Italian health data at the time, he was committed to the defence of public liberties by minimising the scale of the epidemic. He deplored and noted once again a growing tendency to use the state of exception as the normal paradigm of government. In an interview in Le Monde ("L'épidémie montre clairement que l'état d'exception est devenue la condition normale", Le Monde ef 24 March), he recalled that "as Michel Foucault showed before me, secure governments do not necessarily function by producing the situation of exception, but by exploiting it and directing it when it occurs" (Le Monde, 21 March: 22). Responding to this interview, philosopher Emmanuel Faye (Le Monde, 30 March 2020) notes that we must overcome the culture of fear and the form of collective paranoia thus instilled in our modernity [...] Attacks on our rule of law can be fought. Apocalyptic nihilism is never a fatality".

9. The latest report of the Ministry of Home Affairs mentions 60,674 Sri Lankan Tamils living in 107 camps throughout Tamil Nadu (Annual Report of the Ministry of Home AfFairs 2018-2019). Telephone interviews were first conducted in Keezhputhupattu camp and then expanded to other camps in Villupuram (where the camp is located) and Cuddalore districts bordering Pondicherry. This choice is guided by the fact that Pondicherry is an employment centre, functioning as a hub for the people living in these camps. The interviews are still ongoing and are part of a wider survey.

10. As part of the CHALLINEQ programme funded by Equip, surveys interrupted by the crisis were held in February and March in Delhi on housing conditions in the slums of Hanuman Mandir and Madampur Kadar and are now undertaken through phone interviews: http:// www.csh-delhi.com/wp-content/uploads/2019/05/Challengin_Inequalities_Project.pdf

11. According to the definition of the Census of India, the slum category corresponds to a grouping of at least 60 to 70 households, with a minimum population of 300 people, living in 
insecure housing and an unhealthy environment, with a lack of basic infrastructure such as essential water and sanitation services. In 2011, the census counted 367,893 households living in slum. However, the National Statistical Survey, by lowering the slum category threshold to a group of 20 households, estimates 1.02 million households and counts 6363 slums in 2012, almost three times more than the census.

12. http://delhishelterboard.in/main/wp-content/uploads/2017/02/ List_of_additional_jj_bastis.pdf and http://delhishelterboard.in/main/wp-content/uploads/ 2015/09/List-of-JJ-675-Clusters1.pdf

13. According to the NGO SWAN study conducted during containment on 11,159 workers contacted by telephone during the first days of the lockdown, 1,643 were women and children.

14. Rental of "pucca" housing (solid, as opposed to "kaccha", made of temporary materials) is usually around 2,000 - 3,500 rupees/month, and the purchase of walls usually costs around 50,000 rupees (which corresponds to the monthly rental of a T3 in the residential settlements in the nearby wealthy neighbourhood of Safdarjung Enclave), but without any formal right to occupy the land, given the illegal land status of the jhuggi-jhopri clusters.

15. https://www.utpjournals.press/doi/abs/10.3138/cjwl.23.1.097

16. With the implementation of the lockdown, all activities were stopped except those declared as "essential" by the Ministry of Home Affairs (MoHA). A summary of the list published on 24 March by the MoHA is available at this URL: https://economictimes.indiatimes.com/news/ politics-and-nation/heres-a-list-essential-services-that-will-be-available-during-the-21-daynationwide-lockdown/articleshow/74798509.cms

17. The Public Distribution System is a centralized program of food distribution at subsidized prices, legally established by the National Food Security Act of 2013. Department of Food and Public Distribution, 2013. National Food Security Act, 2013 (Online) Available at https:// dfpd.gov.in/nfsa-act.htm.

18. The Pradhan Mantri Jan Dhan Yojana program launched in 2014 facilitates access to banking services for Indian citizens.

19. At the time of writing this article, it is not clear how much these supplementary rations amount to - a priori between 1 and $5 \mathrm{~kg}$ per month- , but it's clear that nothing has yet been done in practice, given the complaints of the people interviewed explaining about the smaller amount of rations that they finally got.

20. https://economictimes.indiatimes.com/news/economy/agriculture/fci-operationshit-in-lockdown-seeks-mention-in-exemption-list/articleshow/74817671.cms?

21. https://ration.jantasamvad.org/ration/

22. Like a majority of employees in the private sector, Radhe Shyam lost his job, even though Central Ministry of Labour and Employment guidelines recommend to employers the continuity of wage payments, which most companies could not commit to without risking bankruptcy.

23. Too numerous to name here, we can mention among others the NGO Chintan which has allowed the delivery of one month's food rations to some of the families identified by the authors of this article. We could also mention Super Sikh Foundation which has delivered hot meals to them all around Delhi, as well as Spandan society which takes care of waste pickers in Bhopura.

24. The relationship to hunger here is rather paradoxical. What emerges from the interviews is that inactivity generated by the impossibility of finding a job increases the number of meals. The refugees interviewed in this way increased from 3 to 5 meals a day. The food consumed is also different. Usually their diet consists mainly of fish, the easy access to which is linked to the employment of a large number of refugees at the nearby fishing port. Since confinement, family meals are almost exclusively vegetarian ( 6 days a week) and include ingredients such as ginger, garlic, lemon, turmeric and tamarind, which are believed to be beneficial for the immune system. Vegetables, like these ingredients, are not available through the PDS. 
25. On average, the surface area of a hut in Hanuman Mandir is just over $9 \mathrm{~m}^{2}$ on the ground inside. For comparison, in France, INSEE considers an overcrowded dwelling from less than $18 \mathrm{~m}^{2}$ per person. On average, a dwelling in Keezhputhupattu is $9 \mathrm{~m}^{2}$. However, these dwellings have been enlarged over time.

26. While the average density in Delhi is 11,320 inhabitants $/ \mathrm{km}^{2}$, it rises to 100,000 inhabitants/ $\mathrm{km}^{2}$ in some districts of old Delhi, and in Hanuman Mandir it exceeds 60,000 inhabitants $/ \mathrm{km}^{2}$ based on built space, it rises to 93,750 inhabitants $/ \mathrm{km}^{2}$.

27. https://www.hindustantimes.com/india-news/domestic-violence-during-covid-19lockdown-emerges-as-serious-concern/story-mMRq3NnnFvOehgLOOPpe8J.html

28. The regular tweets from Arvind Kerjiwal (@ArvindKejriwal) inviting the media to identify gaps in the health system «Grateful to media for pointing out deficiencies. It helps us in reaching relief wherever reqd» 1:01 PM - Mar 28, 2020.

29. https://economictimes.indiatimes.com/news/economy/indicators/extendedlockdown-to-cause-234-4-billion-economic-loss-says-barclays/articleshow/ 75136935.cms?from $=\mathrm{mdr}$

30. A compilation of these deaths reported by the media (thus underestimated) is available here: https://thejeshgn.com/projects/covid19-india/non-virus-deaths/

\section{ABSTRACTS}

In India, on March 24, 2020 at 8:00 pm, the sudden announcement by the Prime Minister of the implementation of containment 4 hours later caused a strong panic among the underprivileged populations. Dramatic images of migrant workers desperately fleeing the big cities to return home have circulated around the world. But not all of them left, far from it, and many had no choice other than to remain confined to the margins. Through various testimonies gathered during the first three weeks of the lockdown in India, this article focuses on the very harsh conditions of confinement of poor populations, whose relegation to the margins was further reinforced by the crisis. In addition to the fact that the protective measures against the virus are impossible to respect there, due to promiscuity and insufficient access to water, the brutal disappearance of everyday livelihood strongly aggravates the low standard of living of the inhabitants. By revealing the paradoxical effects of a confinement that is not adapted to poor neighbourhoods, this article argues for a better consideration of the latter, during and after the pandemic crisis.

En Inde, le 24 mars 2020 à 20h00, l'annonce soudaine par le Premier Ministre de la mise en place d'un confinement 4 heures plus tard a provoqué une forte panique parmi les populations déshérités. Les images dramatiques de travailleurs migrants fuyant désespérément les grandes villes pour retourner chez eux ont fait le tour du monde. Mais tous ne sont pas partis, loin de là, et nombreux sont ceux qui n'avaient pas d'autres choix que de rester confiner dans les marges. A travers différents témoignages recueillis durant les trois premières semaines du lockdown en Inde, cet article porte sur les conditions très dures du confinement des populations pauvres, et dont la crise a encore renforcé la relégation dans les marges. Outre que les " gestes barrières » contre le virus y soient impossibles à respecter, en raison de la promiscuité et d'un moindre accès à l'eau, la disparition brutale des moyens de subsistance aggrave fortement le faible niveau de vie 
des habitants. En révélant les effets paradoxaux d'un confinement non adapté aux quartiers pauvres, cet article plaide pour une meilleure prise en compte des ces derniers, pendant et après la crise pandémique.

\section{INDEX}

Mots-clés: confin, marge, bidonville, camp de réfugiés, virus, confinement, Inde

Keywords: confinement, margin, slum, refugee camps, virus, containment, India

\section{AUTHORS}

\section{RÉMI DE BERCEGOL}

Rémi de Bercegol is a Research fellow at the Centre National de la Recherche Scientifique (CNRS) and a member of USR 3330 Savoirs et Mondes Indiens. He recently published:

- De Bercegol R., Gowda S., (à paraître), Nettoyer l'Inde : la marginalisation des récupérateurs de déchets à Delhi. Dynamiques environnementales [En ligne] (accepté pour publication). URL: https:// journals.openedition.org/dynenviron/

- De Bercegol R., Davis G., Gowda S., 2020. The People of Waste. Living Plastic. Documentaire $18 \mathrm{~min}$ 35 s, IRD-CNRS. URL: https://www.youtube.com/watch?v=ZROTSb2TRsk

- Dejouhanet L., De Bercegol Rémi (coord.), 2019. New Geographies of Collection: Crossed perspectives on modern "gatherers", EchoGéo [Online], n 47. DOI: https://doi.org/10.4000/ echogeo.16477

\section{ANTHONY GOREAU-PONCEAUD}

Anthony Goreau-Ponceaud is a Senior Lecturer at Université de Bordeaux and a member of UMR 5115 LAM ; he is in delegation at the CNRS USR 3330, IFP Pondichéry. He recently published: - Bentz A. S., Goreau-Ponceaud A.y, 2020. To be or not to be a refugee? Reflections on refugeehood and citizenship among Sri Lankan Tamils in India. Citizenship Studies [En ligne], vol. 24, $\mathrm{n}^{\circ}$ 2, p. 176-192. URL: https://www.tandfonline.com/doi/full/ 10.1080/13621025.2019.1706446

- Goreau-Ponceaud A., 2019. Coloniality and tourism: the fabric of identities and alterities in India. Via [En ligne], n 16. URL: http://journals.openedition.org/viatourism/4251 - DOI: https:// doi.org/10.4000/viatourism.4251

- Goreau-Ponceaud A.ny, 2018. Religious dynamics of Sri Lankan Hindu Tamils in Paris: constructions of the self and the other. The Southasianist [En ligne], vol. 6. URL: http:// www.southasianist.ed.ac.uk/article/view/2842

\section{SHANKARE GOWDA}

Shankare Gowda is a research assistant at the Centre of Human Sciences, New Delhi, and at the Centre for Policy Research India. He recently published:

Dupont V. Shankare G., 2020. Slum-free city planning versus durable slums. Insights from Delhi, India. International Journal of Urban Sustainable Development [En ligne], vol. 12, n 1, p. 34-51, DOI: https://doi.org/10.1080/19463138.2019.1666850

- De Bercegol R., Davis G., Gowda S., 2020. The People of Waste. Living Plastic. Documentaire $18 \mathrm{~min}$ 35 s, IRD-CNRS. URL: https://www.youtube.com/watch?v=ZROTSb2TRsk

- De Bercegol R, Gowda S., 2018. Waste and Energy Nexus : rethinking the modernisation of waste 
services in Delhi. Urban Studies, vol. 56, n 11, p. 2297-2314. DOI: https://doi.org/ 10.1177/0042098018770592

\section{ANTONY RAJ}

Antony Raj is a research assistant at the French Institute of Pondicherry. 